DOI 10.7251/SCMED1802112P UDC 616.833.58-009.7 COBISS.RS-ID 7837720

\title{
The Value Assessment of Clinical Trials Based on Electrophysiologically Verified Lumboischialgia
}

\section{ABSTRACT}

Introduction: Lumboischialgia is defined as pain in the distribution of ischemic nerve caused by a pathological change in the nerve itself, whereas lumbago is a localized spondylogenic pain that is not followed by a neurological deficit, and is a consequence of muscular bone dysfunction of the lumbosacral region. Previous studies which investigated the value of clinical trials in the diagnosis of lumboischialgia did not find a high sensitivity and specificity in those tests.

Objective: Our objective was to define clinical tests that indicate the existence of radiculopathy and to determine the value of the overall diagnostic finding in relation to the findings of the EMNG examination.

Methods: The sample consisted of 100 patients of both genders, aged 18-65. The inclusive criteria were: strong lower back pain propagating in one of both legs and lasting for 1-3 months and the medical history suggesting a radicula lesion. Non-inclusion criteria were the following: symptoms of cauda equine, acute febrile condition, existence of tumors, vertebral fractures, lesions of central motoneuron, inability to perform the EMNG examination, acute psychotic conditions, operations of the spine and pregnancy. Immediately before each EMNG examination, medical history was taken with defined questions on the existence of pain stronger in the leg than in the spine, dermatome deficit, pain during labor and weakness in the leg.

Results: Patients usually have a total of two (31\%) and three (26\%) positive clinical signs of lumboischialgia. By statistical analysis, three clinical trials proved to be discriminatory in terms of verification of radiculopathy: positive Lazarevic test, paresis of a particular muscle group, and absence or reduction of the patellar or Achilles reflex. After processing with logistic regression, the statistically predictive value is retained by a positive Lazarevic test. The analysis of the surface under ROC curve shows that the positivity of four or more clinical tests is statistically the best limit value, with a specificity of $67 \%$ and a sensitivity of $56 \%$.

Conclusion: The conducted study indicates the statistical significance of the frequency of positive clinical trials: Lazarevic test, objective muscular weakness and absent reflex, in persons with electrophysiologically verified lumboischialgia.

Key words: clinical signs, radiculopathy, electromyoneurography

(Scr Med 2018:49:112-117)

\section{Draško Prtina ${ }^{1,2}$, Dragan Ostojić ${ }^{\prime}$, Alma Prtina ${ }^{2}$}

\author{
${ }^{1}$ Institute for Physical Medicine \\ and Rehabilitation "Dr Miroslav \\ Zotović, Banja Luka \\ ${ }^{2}$ Faculty of Medicine, University of \\ Banja Luka, Banja Luka, Republic of \\ Srpska, Bosnia and Herzegovina
}

Corresponding author: Draško Prtina e-mail:drprtina@teol.net

Manuscript received: October $15^{\text {th }}, 2018$ Manuscript accepted: October $25^{\text {th }}, 2018$ 


\section{Introduction}

Ischialgia is defined as pain in the distribution of ischemic nerve caused by a pathological change in the nerve itself. Lumbago implies localized spondylogenic pain not accompanied by neurological deficits and is the consequence of muscular bone dysfunction of the lumbosacral region. ${ }^{1}$

Hippocrates (460-357B.C.) first used the term ischias that comes from the Greek word ischios (hip) in its work "Tractat about Diseases ". Under this name, he implied a pain in the hip joint that spreads from buttocks and neck along the thigh and leg. ${ }^{2}$ Laza Lazarević, was a prominent writer of Serbian realism, a doctor, a lawyer and practically the first Serbian neurologist. In his work "Ishias Cotunnii's post " 3,4 he was the first to describe the characteristic sign of the sciatica (from which he himself suffered).

The pain of a radicular character that occurs when lifting the leg is still called Lazarevic's sign. Other clinical cardinal signs of radiculopathy include lower back pain and radiance in the root distribution, often associated with loss of sensitivity and cramps of paravertebral musculature. Motor weakness may also be present. The sensory and motor symptoms of radiculopathy depend on the nerve root or the roots that are damaged. Each nerve root provides a sensation of sensitivity to a specific skin region known as dermatom and motor inertia of certain muscles known as myotoma.

Musculoskeletal reflexes can also show abnormalities in radiculopathy, depending on the damaged nerve root. At the lower extremities, the patella and Achilles reflexes are usually examined. Patelar reflex may be lower in damage to the root of L3, L4, rarely L2. The Achilles reflex is absent and decreased in the root lesion S1. There is no routine reflex for estimating root $\mathrm{L}_{5}$, occasionally a reflex $\mathrm{m}$. tibialis post. and medial hamstrings can be induced. And in case of asymmetry, L5 radiculopathy can be suggested. However, both of these reflexes are often absent in healthy individuals.

EMNG of lower extremities is an objective and highly reliable diagnostic test method for suspected lumbosacral radiculopathy ${ }^{5,6}$ and, according to the protocol, it is performed after a clinical examination. The Needle EMG Analysis of electrical activity in the relaxed muscle and during its contraction determines the level of lesion with a specificity of $85 \%{ }^{7}$

\section{Objective}

The objective is to examine the degree of compatibility of the clinical finding and objectively electrophysiologically verified lumbosacral radiculopathy through the individual definition of the sensitivity and specificity of clinical trials in relation to the same.

\section{Methods}

Basic cohort consisted of 100 patients of both genders, aged 18-65. The inclusive criteria were: strong lower back pain propagating in one of both legs and lasting for 1-3 months and the patient history suggesting a radicula lesion. Non-inclusion criteria were the following: symptoms of cauda equine, acute febrile condition, existence of tumours, vertebral fractures, lesions of central motoneuron, inability to perform nuclear magnetic resonance examination (due to metal objects in the organism, claustrophobia), acute psychotic conditions, inability to perform the EMNG examination (due to the phobia of needles), operations of the spine and pregnancy.

\section{Clinical examination}

The clinical examination, by examining the mobility of the lumbosacral spine and leg, the paralumbar muscular tension, the gross motor power of leg segments, sensitivity and muscular tendon reflexes, was performed just prior to electrophysiological examination, which is a common practice.

\section{Electromyoneurography (EMNG)}

Electrophysiological confirmation of the existence of the acute polyradiculopathy included the registration of the acute denervation in the investigated muscles and long polyphasic potential in more than $30 \%$ of the motor units. In every investigated muscle, 10 different motor units were electrophysiologically studied by estimating the average amplitude, duration and the percentage of polyphasic potential, as well as the degree of regrutation of the voluntary sample.

\section{Analysis of data}

Data obtained through conversation and the electrophysiological examination were imported into the pre-defined data in the software Microsoft Excel 2003. It was ascertained that there were no incorrect data and no missing data. The rest of the analysis was performed by the specialised statistical packages of the SPSS 15.0.17

\section{Results}

Table 1 shows the prevalence in the overall sample of particular clinical signs, such as the Schober sign, Lazarević's sign of the raised leg, the absent reflex, the sensitivity drop, the weakness of the myotoma, and Bell's 
sign of the paralumbular musculature.

Table 1. Prevalence of individual clinical signs in the total sample

\begin{tabular}{|lll}
\hline \multicolumn{1}{|c}{ Sign } & N & $\%$ \\
\hline Schober sign & 61 & 61.0 \\
\hline Lazarević sign & 57 & 57.0 \\
\hline Reflex absent & 41 & 41.0 \\
\hline Sensitivity drop & 34 & 34.0 \\
Weakness of myotoma & 28 & 28.0 \\
\hline Bellov sign & 26 & 26.0 \\
\hline
\end{tabular}

The most common clinical signs in the overall sample of patients with a clinical picture of lumbosacral radiculopathy are Schober's sign (61\%) and Lazarevic's sign (57\%). Distribution of the total number of clinical signs in the total sample is shown in Table 2. Patients in the total sample usually have a total of two (31\%) and three (26\%) positive clinical signs.

Table 2. Distribution of the summed number of clinical signs in the total sample

\begin{tabular}{lcc}
\hline No. of signs & N & $\%$ \\
\hline 0 & 6 & 6.0 \\
1 & 15 & 15.0 \\
\hline 2 & 31 & 31.0 \\
\hline 3 & 26 & 26.0 \\
\hline 4 & 18 & 18.0 \\
\hline 5 & 4 & 4.0 \\
\hline 6 & 0 & 0.0 \\
\hline
\end{tabular}

Patients in the total sample usually have a total of two (31\%) and three (26\%) positive clinical signs.

\section{Table 3. The absence or reduction of the patellar or Achilles reflex}

\begin{tabular}{|c|c|c|c|c|c|c|c|c|c|}
\hline \multirow[t]{3}{*}{ Sign } & \multicolumn{9}{|c|}{ Electromyonurographic finding } \\
\hline & \multicolumn{2}{|c|}{ Negative } & \multicolumn{2}{|c|}{ Positive } & \multirow[b]{2}{*}{$\mathrm{X} 2$} & \multirow[b]{2}{*}{$P^{*}$} & \multirow[b]{2}{*}{$\Phi$} & \multirow[b]{2}{*}{ OR } & \multirow[b]{2}{*}{$95 \% \mathrm{Cl}$} \\
\hline & $\mathrm{N}$ & $\%$ & $\mathrm{~N}$ & $\%$ & & & & & \\
\hline \multicolumn{10}{|l|}{ Bellov sign } \\
\hline Negative & 28 & $(37.8)$ & 46 & $(62.2)$ & 0.42 & 0.637 & 0.06 & 1.37 & $(0.53-3.56)$ \\
\hline Positive & 8 & (30.8) & 18 & $(69.2)$ & & & & & \\
\hline \multicolumn{10}{|l|}{ Schober sign } \\
\hline Negative & 11 & $(28.2)$ & 28 & $(71.8)$ & 1.69 & 0.209 & -0.13 & 0.57 & $(0.24-1.34)$ \\
\hline Positive & 25 & $(41.0)$ & 36 & $(59.0)$ & & & & & \\
\hline \multicolumn{10}{|l|}{ Lazarević sign } \\
\hline Negative & 23 & $(53.5)$ & 20 & $(46.5)$ & 10.02 & 0.003 & 0.32 & 3.89 & $(1.64-9.21)$ \\
\hline Positive & 13 & $(22.8)$ & 44 & $(77.2)$ & & & & & \\
\hline \multicolumn{10}{|l|}{ Sensitivity drop } \\
\hline Negative & 22 & $(33,3)$ & 44 & $(66.7)$ & 0.60 & 0.511 & -0.08 & 0.71 & (0.30-1.68) \\
\hline Positive & 14 & $(41.2)$ & 20 & $(58.8)$ & & & & & \\
\hline \multicolumn{10}{|l|}{ Reflex absent } \\
\hline Negative & 27 & $(45,8)$ & 32 & $(54.2)$ & 5.95 & 0.020 & 0.24 & 3.00 & $(1.22-7.38)$ \\
\hline Positive & 9 & $(22.0)$ & 32 & $(78.0)$ & & & & & \\
\hline \multicolumn{10}{|c|}{ Weakness of myotoma } \\
\hline Negative & 31 & $(43,1)$ & 41 & $(56.9)$ & 5.56 & 0.021 & 0.24 & 3.48 & $(1.19-10.18)$ \\
\hline Positive & 5 & $(17.9)$ & 23 & $(82.1)$ & & & & & \\
\hline
\end{tabular}

\footnotetext{
* Probability calculated on the basis of Fischer's exact test
} 


\section{Clinical signs as individual predictors of positive EMG findings}

When taken into consideration individually, three clinical trials have been shown to be discriminatory in terms of verification of radiculopathy: a positive test of Lazarevic, a paresis of a particular muscle group, and the absence or reduction of the patellar or Achilles reflex (Table 3). However, after the processing by logistic regression, the statistical predictive value is retained by a positive Lazarevic test (Table 4).

Although Table 5 indicates that the sum of specific clinical signs shows a statistically significant predictor property, the analysis of the surface under ROC curve shows that it is only in a zone of poor diagnostic significance.

Table 5. Significance statistics for the sum of clinical trials

Table 4. Clinical signs as individual predictors of positive EMG findings

\begin{tabular}{|c|c|c|c|c|c|}
\hline Sign & $b$ & SEb & $P$ & \multicolumn{2}{|c|}{ OR (95\% i.p.) } \\
\hline Bellov sign & 0.48 & 0.55 & 0.375 & 1.62 & $0.56-4.74$ \\
\hline $\begin{array}{l}\text { Schober } \\
\text { sign }\end{array}$ & -0.90 & 0.51 & 0.076 & 0.41 & $0.15-1.10$ \\
\hline $\begin{array}{l}\text { Lazarević } \\
\text { sign }\end{array}$ & 1.44 & 0.48 & 0.003 & 4.20 & $1.64-10.80$ \\
\hline $\begin{array}{l}\text { Sensitivity } \\
\text { drop }\end{array}$ & -0.29 & 0.51 & 0.572 & 0.75 & $0.28-2.03$ \\
\hline $\begin{array}{l}\text { Reflex } \\
\text { absent }\end{array}$ & 0.69 & 0.54 & 0.206 & 1.99 & $0.69-5.75$ \\
\hline $\begin{array}{l}\text { Weakness } \\
\text { of } \\
\text { myotoma }\end{array}$ & 0.92 & 0.62 & 0.139 & 2.51 & $0.74-8.51$ \\
\hline
\end{tabular}

The overall model is statistically significant : $\chi 2(6)=$ $21,27, P=O, O O 2$

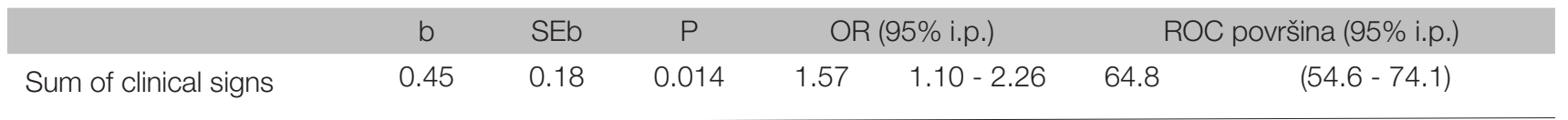

Table 6. Classification table based on the number of clinical signs

\begin{tabular}{lcccc} 
& \multicolumn{3}{c}{ Electromyonurographic finding } \\
\hline $\begin{array}{l}\text { No. of clinical } \\
\text { signs }\end{array}$ & $\mathrm{n}$ & $\%$ & $\mathrm{n}$ & $\%$ \\
\hline 0 & 0 & 0.0 & 0 & 0.0 \\
1 & 4 & 66.7 & 2 & 33.3 \\
\hline 2 & 8 & 53.3 & 7 & 46.7 \\
3 & 12 & 38.7 & 19 & 61.3 \\
4 & 7 & 26.9 & 19 & 73.1 \\
5 & 5 & 22.7 & 17 & 77.3 \\
6 & 0 & 0.0 & 0 & 0.0 \\
\hline
\end{tabular}

Table 6 shows the classification based on the number of clinical signs, and Table 7 is the diagnostic classification value based on the number of clinical signs.
Table 7. Diagnostic classification value based on the number of clinical signs

\begin{tabular}{lrrcr}
$\begin{array}{l}\text { No. of } \\
\text { clinical }\end{array}$ & Sensitivity & $95 \%$ i.p. & Specificity & $95 \%$ i.p. \\
signs & & & & \\
$\begin{array}{l}1 \text { and } \\
\text { more }\end{array}$ & 100 & $94.3-100.0$ & 0 & $0.0-9.8$ \\
$\begin{array}{l}2 \text { and } \\
\text { more }\end{array}$ & 96.87 & $89.1-99.5$ & 11.11 & $3.2-26.1$ \\
$\begin{array}{l}3 \text { and } \\
\text { more }\end{array}$ & 85.94 & $75.0-93.3$ & 33.33 & $18.6-51.0$ \\
4 and & 56.25 & $43.3-68.6$ & 66.67 & $49.0-81.4$ \\
more & & & & \\
5 & 26.56 & $16.3-39.1$ & 86.11 & $70.5-95.3$ \\
\hline
\end{tabular}

* Maximum value of the Iouden index, which, statistically speaking, represents an optimal limit value

The positivity of four or more clinical tests is statistically the best limit value, with a specificity of $67 \%$ and a sensitivity of $56 \%$ in the diagnosis of LS radiculopathy (EN1). 


\section{Discussion}

The values of the clinical findings are being increasingly neglected in relation to excessive and almost exclusive use of visualization methods of testing. However, an isolated clinical trial of patients with symptoms of lumbar radiculopathy does not often give satisfactory conclusions. Electrophysiological examination can be very useful in the diagnosis oflumbosacral radiculopathies by determining the degree and level of the lesion, but also by excluding the existence of peripheral nervous lesions due to other causes. The true diagnostic accuracy and the value of clinical trials of lumbar radiculopathies provokes numerous debates. The sensory deficit, the absence of deep tendon reflexes, and motor weakness may be present at a different degree of manifestation and in different diseases. The loss of tendon reflexes is often taken with the utmost certainty to confirm the actual radiculopathy: the patellar reflex for the roots L2 and $\mathrm{L} 3$, the variable reflex $\mathrm{m}$. tibialis post. for the root of $\mathrm{L} 5$, and Achill's root-root reflex S1. It is generally accepted that these clinical tests record good specificity, but low sensitivity. In our research, the asymmetry of reflex, muscle paresis and Lazarevićs sign show a predictive diagnostic value for lumbosacral radiculopathies, but in total with poor diagnostic significance precisely because of low sensitivity.

In any case, the values of the specificity and sensitivity of particular clinical data obtained in this study are slightly lower than previously published. The differences in studies originate primarily from differences in the population sample, and partly in the different designs of studies. ${ }^{11}$

In our study, the positive finding of the defined clinical trials was not an including factor for entering the study, and therefore potential verification burden was avoided. ${ }^{12}$ It is also evident that our examination included a sample of general population without isolating specific population samples, thereby avoiding new restrictions. For example, both sexes are equally represented, while the majority of the previous trials included approximately twice as many men. In order to avoid asymptomatic patients and insignificant problems, only patients with severe pain in the lower part of the back that radiated to the legs and caused significant disability, were involved. These symptoms are generally accepted anamnestic parameters of acute lumbosacral radiculopathies.

According to the research, independent indicators of actual radiculopathy in the clinical finding are:

- Objective muscle weakness,

- Positive Lazarevic test,
- Absent reflex

Such findings are in line with existing clinical practice experience. It is surprising that there is no dermatomic sensitivity outbreak as a predictor of radiculopathy, although it was expected that the Schober test would be a predictor of radiculopathy, primarily due to the stretching of the meninge and roots, but also because of the reversal of lumbar lordosis, which has a mechanical protective effect on the present herniation of the disc. This sign did not prove to be predictive in this study. The position of the lumbar spine opens up the space of the last part of the intervetebral space and could aggravate and intensify the present herniation. However, most other causes of pain in the back of non-radicular etiology would limit this movement. For this reason, the anteflective test is insufficiently specific. ${ }^{13}$ It appears that this test also indicates the irritation and tension of the root, and not just the compression. ${ }^{14}$ The clinical sign of lifting the stretched leg, that is, Lazarević's sign, was the only one among the studied clinical trials proved predictive and through statistical method of logistic regression. This finding is expected because this sign proved to be highly sensitive (91\%), but low in specificity (up to $45 \%$ ). ${ }^{15,16}$

\section{Conclusion}

The performed study indicates the statistical significance of the clinical tests of the raised leg, i.e. the Lazarevic test, the objective weakness of the muscle and the absent reflex, in the diagnosis of lumbosacral radiculopathy. A detailed clinical examination can lead to a quicker and easier diagnosis, as well as to significant savings in the healthcare system, avoiding often unnecessary additional diagnostic procedures.

\section{References}

1. Koes BW, Tulder MW van, Ostelo R, Burton AK, Waddwll G. Clinical guidelines for the menagement of low back pain in primari care: an international comparison. Spine. 2001;26:2504-13.

2. Hippocrates (460-370 BC). The Genuine Works of Hippocrates. Translation- Adams F. London: Sydenham Society, 1849.

3. Lazarević LK. Ischias postica Cotunnii - Jedan prilog za njenu diferencijalnu dijagnozu. Srp Arh Celok Lek 1880;7:23-35.

4. Lazarević LK. Ischias postica Cotunnii Ein Beitrag zu deren Differential-Diagnose Allg Wien Med Zeitung 1884;38:437-8.

5. Kishner S, Gündüz H, Munshi S. Electrodiagnosis in lumbar spinal stenosis a review. Turk J Phys Med Rehab 2010;56:75-80.

6. Rubinstein SM, von Tulder M. A best-evidence review of 
diagnosis procedures for neck and low-back pain. Best Pract Res Clin Rheumatol 2008;22(3):471-82.

7. Heydari A, Nargol AV, Jones AP, Humphrey AR. EMG analysis of lumbar paraspinal muscles as a predictor of the risc of low-back pain. Eur Spine J 2010;19(7):1145-52.

8. Cho, S.C, Ferrante, M.A, Levin, K.H, Harmon, R.L, So, Y.T. Utility of electrodiagnostic testing in evaluating patients with lumbosacral radiculopathy: an evidence-based review. Muscle Nerve 2010; 42: 276-282

9. SPSS 15.0 Command Syntax Reference 2006, Chicago Ill., USA: SPSS Inc., 2006.

10. Deyo RA, Mirza SK, Martin BI. Back pain prevalence and visit rates: estimates from U.S. national surveys, 2002. Spine 2006;31:2724-7.

11. Hoogen HJMM, KOES BW,van Eijck JTM. On the accurancy of history, phisical examination and erythrocyte sedimentation rate in diagnosis low-back pain in general practice. Spine 1995;20:318-27.

12. Vroomen PCAJ, de Krom MCTFM, Knottnerus JA.
Diagnostic value of history and physical examination in patients with sciatica due to disc herniation; a systematic review. J Neurol.1999;246:899-906.

13. Murade E, Neto JS, Avanzi O. Study of relationship and importance of clinical semiology, axial computet tomography and electroneuromyography in lumbar radiculopathies. Acta Ortop Bras 2002;10(4):18-25.

14. Knotnerus JA. The effects of disease verifiaction and referral on there releationship between symptoms and disease. Med Desic Making.1987;7:139-48.

15. Deville WL, van der Windt DA, Dzaferovic A, Bezemer PD, Bouter LM. The test of Lasegue: systematic review of the accuracy in diagnosis herniated discs. Spine 2000;25(9):1140-7.

16. Rabin A, Gerszten PC,Karausky P, Bunker CH, Potter DM, Welch WC. The sensitivity of the seated straigth-leg raise test compared with the supine straight-leg raise test in patient presenting with magnetic resonance imaging evidence of lumbar nerve root compression. Arch Phys Med Rehabil 2007;88(7):840-3.

\section{Procjena vrijednosti kliničkih testova na osnovu elektrofiziološki verifikovane lumboishijalgije}

\section{SAŽETAK}

Uvod: Lumboishijalgija se definiše kao bol u distribuciji ishijadičnog nerva uzrokovana patološkom promjenom samog nerva, dok je lumbago lokalizovani spondilogeni bol koji nije praćen neurološkim deficitom i posljedica je mišićno koštane disfunkcije lumbosakralne regije. Dosadašnje studije koje su istraživale vrijednost kliničkih testova u dijagnostici lumboishijalgija nisu našle visoku senzitivnost i specifičnost ispitivanih testova.

Cilj rada: Cilj nam je bio definisati kliničke testove koji ukazuju na postojanje radikulopatije i utvrditi vrijednost cjelokupnog dijagnstičkog nalaza u odnosu na nalaz EMNG pregleda.

Metode: Istraživanje je provedeno na uzorku od 100 pacijenta, oba pola, starosti od 18-65 godina. Inkluzioni kriterijumi su bili jak bol u donjem dijelu leđa sa širenjem u jednu ili obe noge u trajanju od jednog do tri mjeseca i klinička slika koje jasno sugeriše postojanje radikularne lezije. Ekskluzioni kriterijumi su bili: simptomi caudae equinae, akutna febrilna stanja, postojanje tumora, frakture pršljenova, lezije centralnog motornog neurona, akutna psihotična stanja, nemogućnost elektromiografskog pregleda. Svakom EMNG pregledu je prethodio detaljan klinički pregled.

Rezultati: Pacijenti najčešće imaju ukupno dva (31\%) i tri (26\%) pozitivna klinička znaka lumboishijalgije. Statističkom analizom tri klinička testa su se pokazala diskriminativna u pogledu verifikacije radikulopatije: pozitivan test Lazarevića, pareza određene mišićne grupe, te odsustvo ili redukcija patelarnog ili Ahilovog refleksa. Nakon obrade logističkom regresijom, statistički prediktivnu vrijednost zadržava pozitivan test Lazarevića. Analiza površine pod ROC krivom pokazuje da pozitivnost četiri i više kliničkih testova predstavlja statistički gledano najbolju graničnu vrijednost, sa specifičnošću od 67\% i senzitivnošću od $56 \%$.

Zaključak: Provedena studija ukazuje na statističku značajnost učestalosti pozitivnih kliničkih testova: Lazarević testa, objektivne slabosti mišića i ispada refleksa, kod osoba sa elektrofiziološki verifikovanom lumboishialgijom.

Ključne riječi: lumboishijalgija, klinički testovi, EMNG 